\title{
KONDISI TERUMBU KARANG DI PERAIRAN LIUKANG TANGAYA KABUPATEN PANGKAJENE DAN KEPULAUAN
}

\author{
Iwan Nurhidayat ${ }^{1)}$, Rustam 2), Abdul Rauf3) \\ 1Program Pascasarjana Universitas Muslim Indonesia \\ ${ }^{2}$ Dan ${ }^{3}$ Dosen IImu Kelautan Fakultas Perikanan dan Kelautan Universitas Muslim Indonesia \\ inurhidayat81@gmail.com
}

\begin{abstract}
ABSTRAK
Terumbu karang adalah salah satu ekosistem yang memiliki peranan yang sangat penting dalam sebuah perairan, produktifitas dan keanekaragaman hayati yang tinggi merupakan ciri dari ekosistem ini terumbu karang dan segala kehidupan yang terdapat di dalamnya merupakan salah satu kekayaan alam yang bernilai tinggi. Penelitian ini dilaksanakan bulan Juli sampai Oktober 2018. Tujuan Penelitian ini adalah untuk mengetahui kondisi terumbu karang yang ada di Periaran Liukang Tangaya. Pengambilan data terumbu karang menggunakan metode (Underwater Photo Transect $=$ Transek Foto Bawah Air). Hasil penelitian di 14 Pulau dengan 15 stasiun pengamatan menunjukan bahwa kondisi terumbu karang di Liukang Tangaya secara umum berada pada kondisi rusak dengan rata-rata tutupan karang hidup hanya $18.91 \%$ dengan penyebab kerusakan utama adalah karena aktifitas penangkapan ikan yang tidak ramah lingkungan.
\end{abstract}

\section{Kata kunci: terumbu karang liukang Tangaya rusak}

\section{ABSTRACT}

Coral reef is one of the most important ecosystem in marine environment. With high biodiversity and productivity as one of their characteristic makes coral reef value in nature regulation cannot be replaced. This study held from July until October 2018. The aim of this study is to understand coral reefs in Liukang Tangaya waters. Data collection using Underwater Photo Transect method. The result are, from 15 observation station show that coral reefs in Liukang Tangaya in damaged condition with average of live coral is $18.91 \%$ with the main cause come from destructive fishing.

\section{Keywords: the Liukang Tangaya coral reef was damaged}

\section{PENDAHULUAN}

Terumbu karang adalah salah satu ekosistem yang memiliki peranan yang sangat penting dalam sebuah perairan, produktifitas dan keanekaragaman hayati yang tinggi merupakan ciri dari ekosistem ini terumbu karang dan segala kehidupan yang terdapat di dalamnya merupakan salah satu kekayaan alam yang bernilai tinggi. Manfaat yang terkandung di dalam ekosistem terumbu karang sangat besar dan beragam, baik manfaat langsung maupun tidak langsung, salah satu manfaat langsung dari terumbu karang adalah tempat hidupnya ikan tangkapan nelayan, selain itu terumbu karang juga dapat menjadi objek wisata karena panoramanya yang bernilai estetika tinggi.

Terumbu karang merupakan salah satu indikator yang dilihat apabila suatau kawasan akan dijadikan kawasan konservasi, dalam penentuan zonasi kawasan konservasi biasanya dilihat dari kondisi terumbukarangnya, kondisi terumbu 
karang yang baik biasanya akan dijadikan zona inti suatu kawasan walaupun hal tersebut tidaklah mutlak.

Perairan Liukang Tangaya masuk dalam wilayah perairan Kabupaten Pangkajene dan Kepulauan Provinsi Sulawesi Selatan, Liukang Tangaya berbatasan langsung dengan Provinsi Nusa Tenggara Barat. Dalam dokumen Rencana Zonasi Wilayah Pesisir dan Pulau-Pulau Kecil (RZWP3K) Provinsi Sulawesi Selatan wilayah Liukang Tangaya merupakan salah satu wilayah yang rencananya akan dicadangkan jadi kawasan konservasi, oleh karena salah satu data yang diperlukan adalah data mengenai kondisi terumbu karang yang ada di Liukang Tangaya. Tujuan dari penelitian ini adalah untuk mengetahui kondisi terumbu karang yang ada di Periaran Liukang Tangaya.

\section{METODOLOGI PENELITIAN}

Penelitian ini dilaksanakan selama 3 bulan dari mulai bulan Juli sampai Oktober 2018 di Kecamatan Liukang Tangaya Kabupaten Pangkajene dan Kepulauan. Pengambilan data ekosistem terumbu karang di lapangan dilakukan dengan penyelaman menggunakan peralatan selam SCUBA dengan metode UPT (Underwater Photo Transect $=$ Transek Foto Bawah Air) (Giyanto dkk, 2014). Adapun teknis pelaksanaan metode UPT di lapangan adalah sebagai berikut:

- Menarik dan meletakkan garis transek dengan menggunakan roll meter (pita berskala) sepanjang 50 meter pada kedalaman 5 dan $10 \mathrm{~m}$ pada kedalaman dimana karang umum dijumpai dan sejajar garis pantai, dimulai dari titik awal sebagai meter ke-0. Untuk keseragaman dalam penarikan garis transek, posisi pulau berada di sebelah kiri garis transek.

- Setelah garis transek terpasang, dilakukan pemotretan dengan mengunakan kamera untuk mengetahui kondisi habitat sekitar garis transek dan mendapatkan gambaran umum/deskripsi dasar perairan di sekitar garis transek. Pemotretan dimulai dari meter ke 1 pada bagian sebelah kiri garis transek (bagian yang lebih dekat dengan daratan) sebagai "Frame 1" (Gambar 1), dilanjutkan dengan pengambilan foto pada meter ke-2 pada bagian sebelah kanan garis transek (bagian yang lebih jauh dengan daratan) sebagai "Frame 2", dan seterusnya hingga akhir transek. Jadi untuk frame dengan nomor ganjil (1, $3,5, \mathrm{dst}$ ) diambil pada bagian sebelah kiri garis transek, sedangkan untuk frame dengan nomor genap (2, 4, 6, dst) diambil pada bagian sebelah kanan garis transek.

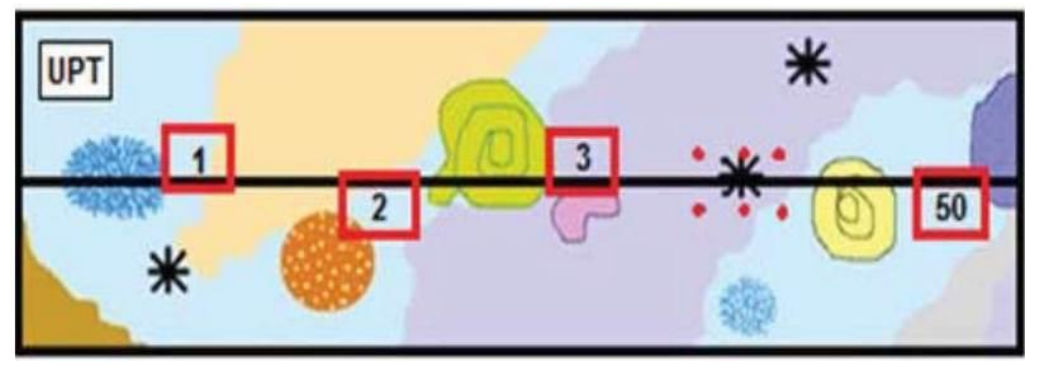

Gambar 1. Ilustrasi Dalam Penarikan Sampel Dengan Metode UPT 
- Setelah itu mulai dilakukan pengambilan data dengan melakukan pemotretan bawah air, dimana sudut pengambilan foto tegak lurus terhadap dasar substrat. Luas area minimal bidang pemotretan adalah $2552 \mathrm{~cm}^{2}$ atau $(58 \times 44) \mathrm{cm}^{2}$. Untuk memperoleh luas bidang pemotretan sekitar $2552 \mathrm{~cm}^{2}$, pemotretan dilakukan pada jarak $60 \mathrm{~cm}$ dari dasar substrat.

Analisis foto berdasarkan foto hasil pemotretan dilakukan menggunakan komputer dan piranti lunak (software) CPCe (Kohler \& Gill dalam Giyanto dkk, 2014). Sebanyak 30 sampel titik acak dipilih untuk setiap frame foto, dan untuk setiap titiknya diberi kode sesuai dengan kode masingmasing kategori dan biota dan substrat yang berada pada titik acak tersebut.

Untuk mendapatkan data-data kuantitatif berdasarkan foto-foto bawah air yang dihasilkan dari metode UPT ini, analisis data dilakukan terhadap setiap frame dengan cara melakukan pemilihan sampel titik acak. Teknik ini digunakan dengan menentukan banyaknya titik acak (random point) yang dipakai untuk menganalisis foto. Jumlah titik acak yang digunakan adalah sebanyak 30 buah untuk setiap framenya, dan ini sudah representatif untuk menduga persentase tutupan kategori dan substrat (Giyanto dkk, 2014). Teknik ini merupakan aplikasi dari penarikan sampel, dimana sebagai populasinya adalah semua biota dan substrat yang terdapat dalam frame foto, sedangkan sampelnya adalah titik-titik yang dipilih secara acak pada foto tersebut. Dengan cara ini, data yang dicatat hanyalah biota dan substrat yang berada tepat pada posisi titik yang telah ditentukan secara acak oleh software CPCe.
Berdasarkan proses analisis foto yang dilakukan terhadap setiap frame foto yang dilakukan, maka dapat diperoleh nilai persentase tutupan kategori untuk setiap frame dihitung berdasarkan rumus sebagai berikut:

$$
\begin{aligned}
& \text { Persentase tutupan kategori } \\
& =\frac{\text { Jumlah titik kategori }}{\text { Banyaknya titik acak }} \times 100 \%
\end{aligned}
$$

Perhitungan persentase tutupan karang hidup dengan menjumlahkan persentase kehadiran hard coral, soft coral, dan other. Kondisi penilaian ekosistem terumbu karang berdasarkan kisaran tingkat persentase penutupan karang (Gomez dan Yap 1988 dalam Giyanto dkk, 2014), yaitu:

- Rusak, bila persen tutupan karang hidup antara 0-24,9\%

- Sedang bila persen tutupan karang hidup antara 25-49,9\%

- Baik bila persen tutupan karang hidup antara $50-74,9 \%$, dan

- Sangat baik apabila persen tutupan karang batu hidup $75-100 \%$

\section{HASIL DAN PEMBAHASAN}

\section{Kondisi Kualitas Perairan}

Pengukuran kualitas perairan dilakukan di 12 stasiun pengamatan, pada saat penelitian cuaca rata-rata dalam kondisi cerah. Adapun parameter kualitas perairan yang diukur adalah Suhu, Salinitas, Kecerahan, Oksigen Terlarut dan pH.

Suhu merupakan salah satu faktor utama dalam proses pertumbuhan bagi terumbu karang. Kisaran suhu pada suatu tempat sangat dipengaruhi oleh intensitas cahaya matahari yang masuk ke perairan, salinitas air laut dan arus-arus global. Hasil pengamatan suhu yang dilakukan di Kecamatan Liukang Tangaya pada 12 pulau 
menggambarkan bahwa suhu yang ada masih relatif normal bagi pertumbuhan karang. Kisaran suhu di 12 pulau tersebut adalah $28,42-31,35^{\circ} \mathrm{C}$ dengan suhu ratarata $29,85^{\circ} \mathrm{C}$. Kisaran suhu tertinggi terjadi di Pulau Sabaru yakni $31,35^{\circ} \mathrm{C}$. Kondisi suhu permukaan air laut tiap lokasi pengamatan di Kecamatan Liukang Tangaya masih sesuai dengan baku mutu air laut Keputusan Menteri Lingkungan Hidup No 51 tahun 2004 yaitu alami (28$30^{\circ} \mathrm{C}$ ). Lebih lanjut Supriharyono (2007) menyatakan bahwa suhu yang baik untuk pertumbuhan karang berkisar antara $25^{\circ} \mathrm{C}$ $2^{\circ} \mathrm{C}$, batas minimum $16^{\circ} \mathrm{C}-17^{\circ} \mathrm{C}$ dan batas maksimum sekitar $36^{\circ} \mathrm{C}$.

Salinitas berpengaruh terhadap reproduksi, distribusi, lama hidup serta orientasi migrasi. Perbedaan kisaran salinitas pada perairan yang jauh dari pantai akan relatif kecil dibandingkan dengan variasi salinitas di dekat pantai. Salinitas di lokasi pengamatan relatif homogen antara 34,57-34,78 PSU dengan rata-rata salinitas 34,67 PSU. Berdasarkan Keputusan Menteri Lingkungan Hidup No 51 tahun 2004 tentang baku mutu air laut untuk biota perairan salinitas di perairan Liukang Tangaya masih sesuai untuk pertumbuhan biota. Salinitas tertinggi terdapat di perairan Pulau Sarege (34,78 PSU) dan terendah di Pulau Kembang Lemari (34,57 PSU). Penyebab adanya perubahan salinitas di perairan laut ini sangat bervariasi umumnya tergantung pada faktor alam, seperti run-off sungai, badai, hujan, sehingga kisaran salinitas dapat berubah drastis (Vaughan dan Wells, 1.943 dalam Supriharyono 2000).

Hasil pengukuran $\mathrm{pH}$ di perairan Kecamatan Liukang Tangaya masih dalam kategori yang stabil dengan nilai pH 8,21. Kondisi ph yang demikian di perairan Liukang Tangaya, berdasarkan Keputusan Menteri Lingkungan Hidup No 51 tahun 2004 merupakan $\mathrm{pH}$ yang cocok untuk pertumbuhan biota dimana nilai $\mathrm{pH}$ berdasarkan Keputusan Menteri Lingkungan Hidup adalah 7-8,5. Perubahan harian nilai $\mathrm{pH}$ yang tidak terlalu ekstrim dan dalam waktu yang singkat pada suatu perairan tidak terlalu mempengaruhi organisme perairan. Fitoplankton dan vegetasi perairan lainya menyerap karbon dioksida dari perairan selama proses fotosintesa berlangsung sehingga $\mathrm{pH}$ cenderung meningkat pada siang hari dan menurun pada malam hari (Nontji, 2005).

Karakteristik perairan Liukang Tangaya kondisinya yang terbuka, oksigen terlarut berada pada kondisi alami dengan kisaran 6,70-8,30 mg/l, sehingga jarang dijumpai di perairan terbuka yang miskin oksigen (Brotowidjoyo, dkk., 1995). Walaupun pada kondisi terbuka, kandungan oksigen perairan tidak sama dan bervariasi berdasarkan siklus, tempat dan musim. Kadar oksigen terlarut juga berfluktuasi secara harian, musiman, pencampuran masa air, pergerakan masa air, aktifitas fotosintesa, respirasi dan limbah yang masuk ke badan air (Effendy, 2003). Di bawah ini adalah tabel lengkap hasil pengukuran kualitas perairan di Liukang Tangaya : 
Tabel 1. Hasil pengukuran kualitas perairan

\begin{tabular}{|c|l|c|c|c|c|c|}
\hline No & \multicolumn{1}{|c|}{ Pulau } & $\begin{array}{c}\text { Salinitas } \\
\text { (PSU) }\end{array}$ & $\begin{array}{c}\text { Suhu ( } \\
\circ \mathbf{C})\end{array}$ & DO & pH & Kecerahan \\
\hline 1 & Sabaru & 34.63 & 31.35 & 7.9 & 8.3 & 98 \\
\hline 2 & Sumanga & 34.65 & 28.73 & 7.4 & 8.4 & 98 \\
\hline 3 & Lilikang & 34.64 & 29.25 & 6.7 & 8.3 & 98 \\
\hline 4 & Sanipa & 34.7 & 28.86 & 8.2 & 7.9 & 98 \\
\hline 5 & Sarege & 34.78 & 31.06 & 8.1 & 8.3 & 98 \\
\hline 6 & Pelokan Lompo & 34.72 & 30.51 & 7.9 & 8.4 & 98 \\
\hline 7 & Pelokan Caddi & 34.72 & 30.51 & 7.9 & 8.4 & 98 \\
\hline 8 & Sambarjaga & 34.67 & 30.61 & 8.3 & 8.4 & 98 \\
\hline 9 & Sapuka Caddi & 34.68 & 30.8 & 6.7 & 7.9 & 98 \\
\hline 10 & Kembang Lemari & 34.57 & 28.42 & 6.9 & 7.9 & 98 \\
\hline 11 & Cakalangan & 34.59 & 29.64 & 6.9 & 7.9 & 98 \\
\hline 12 & Lamuruang & 34.74 & 28.5 & 8.1 & 8.4 & 98 \\
\hline
\end{tabular}

Kecerahan perairan Liukang Tangaya

menunjukkan kemampuan penetrasi cahaya sekitar $98 \%$ untuk menembus lapisan air pada kedalaman tertentu. Kecerahan perairan dipengaruhi oleh bahan-bahan halus yang melayang-layang dalam air baik berupa bahan organik seperti plankton, jasad renik, detritus maupun berupa bahan anorganik seperti lumpur dan pasir (Hargreaves, 1999). Banyak sedikitnya sinar matahari yang menembus ke dalam perairan sangat bergantung dari kecerahan air. Besarnya nilai penetrasi cahaya ini dapat diidentifikasikan dengan kedalaman air yang memungkinkan masih berlangsungnya proses fotosintesis (Barus, 1996).

\section{Kondisi Terumbu Karang}

Pengamatan kondisi terumbu karang dilakukan di 14 Pulau dengan 15 stasiun pengamatan, dari hasil pengamatan didapatkan bahwa karang di Liukang Tangaya terdiri dari beberapa genus diantaranya Acropora, Pocillapora, Montipora, Porites, Sinularia, Goniastrea, dan beberapa karang hias dari genus Euphyllia. 


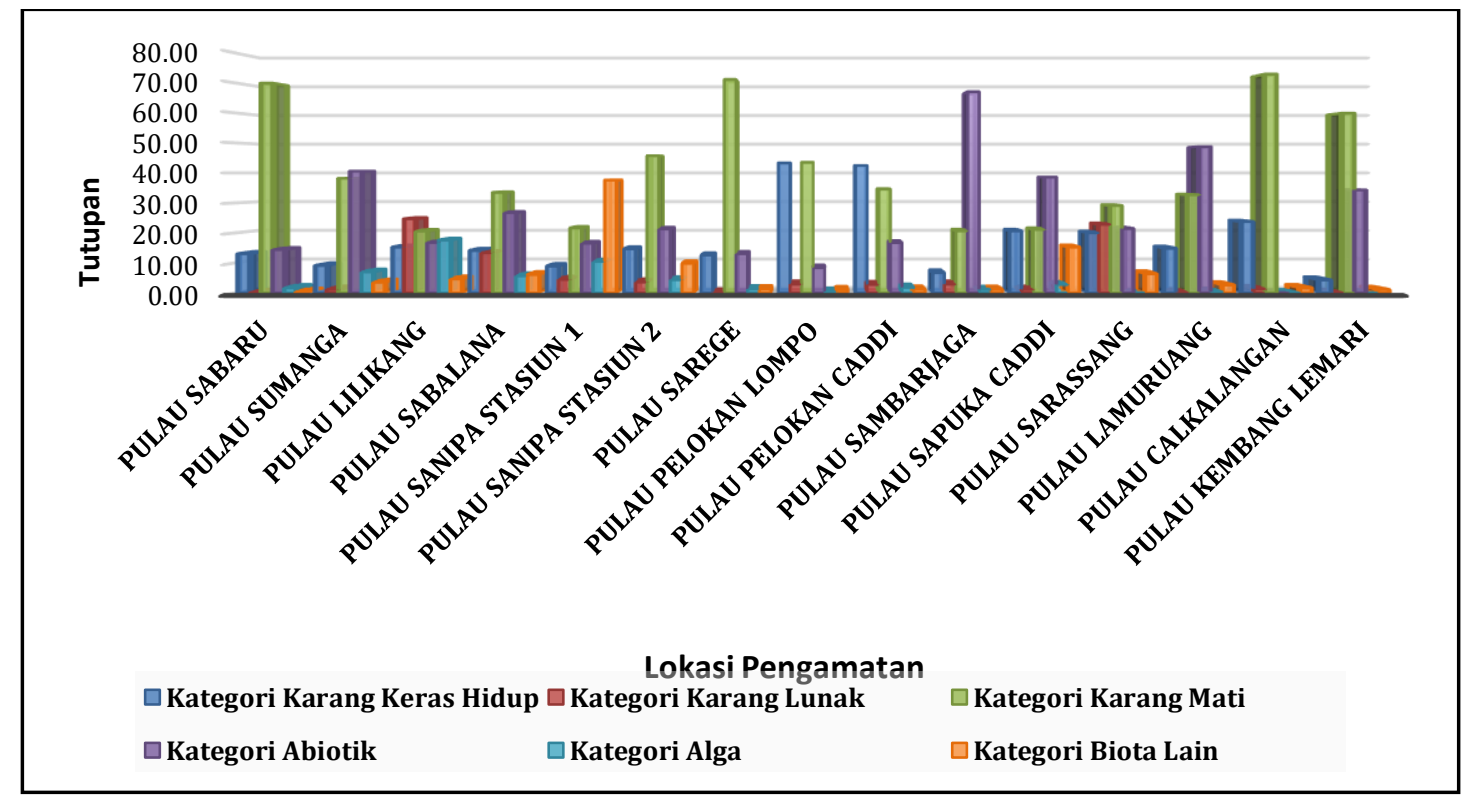

Gambar 2. Komposisi tutupan karang Liukang Tangaya

Berdasarkan hasil olahan data dengan menggunakan software Cpce didapatkan kategori karang mati dan abiotik sangat mendominasi tiap lokasi pendataan kondisi karang di Kecamatan Liukang Tangaya (Gambar2). Kategori karang mati yang terdapat di Kecamatan Liukang Tangaya terdiri dari karang mati yang ditumbuhi alga serta karang mati akibat kenaikan suhu (pemutihan karang atau bleaching). Dari grafik terlihat karang mati yang memiliki nilai persentase tertinggi yaitu Pulau Cakalangan (72,87\%) diikuti Pulau Sarege $(71,09 \%)$ dan Pulau Sabaru $(69,87 \%)$. Sementara itu untuk kategori abiotik yang teridentifikasi terdiri dari pasir dan patahan karang. Lokasi pengamatan yang memiliki nilai tertinggi dari kategori abiotik terletak di Pulau Sambarjaga (67\%) yang didominasi oleh pasir. Hasil pengamatan dilapangan lokasi dengan patahan karang terbanyak dijumpai di Pulau Sapuka Caddi (24,73\%), Pulau Sambarjaga $(24,70 \%)$. Pulau Kembang Lemari $(24,47 \%)$, dan Pulau Lamuruang (15,93\%). Tingginya patahan karang di beberapa lokasi pengamatan khususnya di 4 pulau (Pulau Sapuka Caddi, Pulau Sambarjaga, Pulau Kembang Lemari dan Pulau Lamuruang) mengindakasikan di Kecamatan Liukang Tangaya masih sering dilakukan penangkapan ikan dengan menggunakan alat tangkap yang tidak ramah lingkungan seperti penggunaan trawl, bom dan bius serta pukat harimau yang mengakibatkan rusaknya terumbu karang di perairan Kecamatan Liukang Tangaya.

Karang lunak yang paling tinggi persentasenya dijumpai di Pulau Lilikang $(24,73 \%)$ dan Pulau Sarassang (22,87\%). Kategori alga paling banyak terdapat di Pulau Lilikang $(17,67 \%)$ dan Pulau Sanipa stasiun 1 (10,53\%). Tingginya persentase karang lunak dan alga di tiap lokasi pengamatan menandakan karang baru yang akan tumbuh tidak dapat bersaing dengan karang lunak dan alga sehingga karang yang sudah mati secara langsung ditutupi dan ditumbuhi oleh karang lunak maupun alga. Selain itu berdasarkan hasil pengamatan terlihat karang yang telah mati juga banyak ditumbuhi oleh sponge. 
Sementara itu untuk kategori biota, Pulau Sanipa stasiun 1 memiliki persentase biota yang paling tinggi yakni 37,60\% diikuti Pulau
Sapuka Caddi $15,33 \%$. Jenis biota yang teridentifikasi umumnya di dominasi oleh sponge, ascidian dan bintang laut.

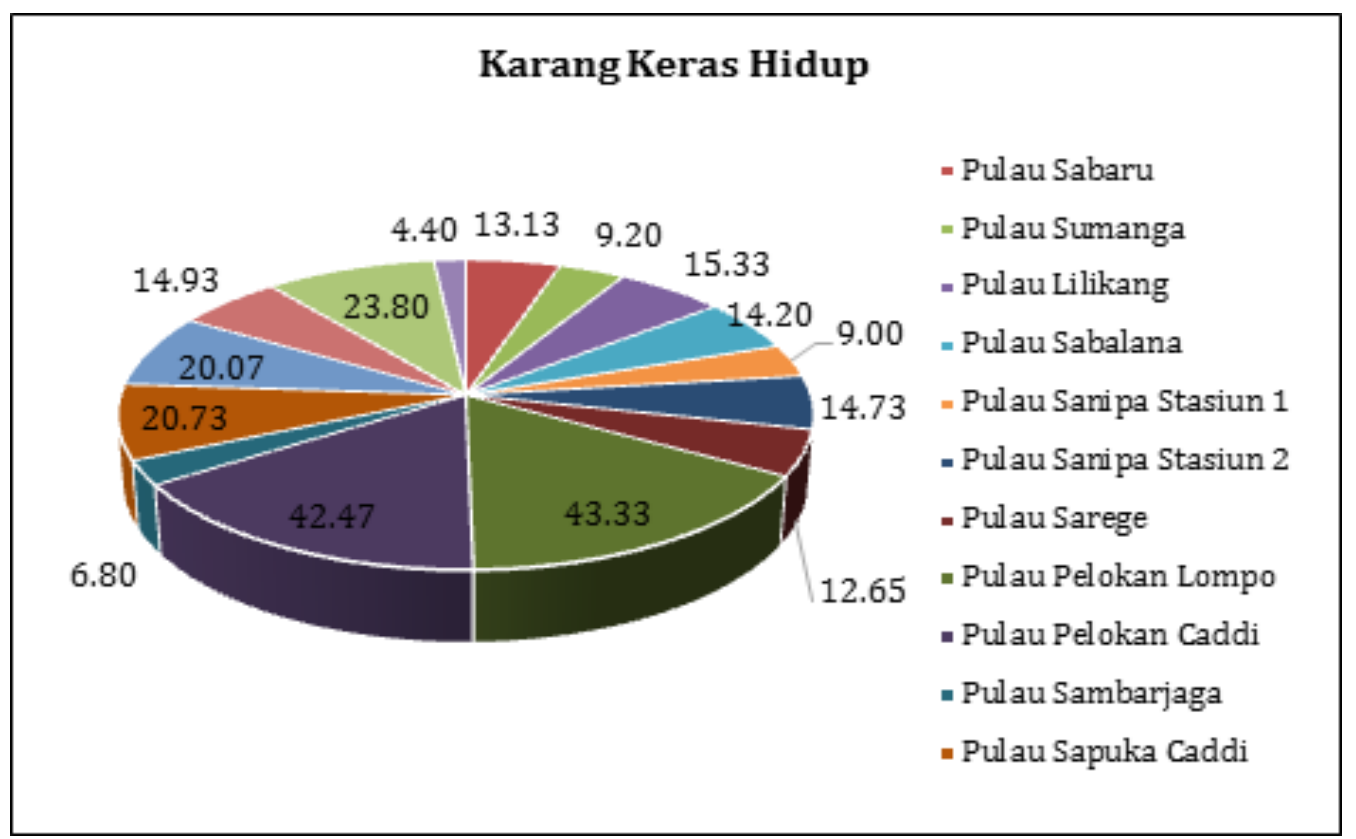

Gambar 3. Tutupan karang hidup di Liukang Tangaya

Untuk kategori karang keras hidup didapatkan bahwa kondisi karang di tiap stasiun pengamatan berada dalam kondisi rusak dan sedang (Gambar 3). Kondisi karang dalam kategori sedang berada di Pulau Pelokan Lompo dengan tutupan karang keras hidup 43,33\% dan Pulau Pelokan Caddi (42,47\%) sedangkan kondisi karang rusak berada di 12 pulau yakni Pulau Sabaru, Sumanga, Lilikang, Sabalana, Sanipa (2 stasiun), Sarege, Sambarjaga, Sapuka Caddi, Sarassang, Lamuruang, dan Cakalangan. Kembang Lemari merupakan pulau dengan persentase tutupan karang keras hidup paling rendah yakni hanya $4,40 \%$, Secara umum kondisi terumbu karang di Kecamatan Liukang Tangaya berada dalam kondisi "Rusak" dengan jumlah persentase hanya $18.91 \%$ hal tersebut mengacu pada (Gomes dan Yap dalam Giyanto, 2014).

\section{KESIMPULAN}

Berdasarkan hasil penelitian di 14 Pulau di Liukang Tangaya dapat disimpulkan bahwa kondisi terumbu karang di Liukang Tangaya secara umum berada pada kondisi rusak dengan penyebab kerusakan utama adalah karena aktifitas peneangkapan ikan yang tidak ramah lingkungan.

\section{DAFTAR PUSTAKA}

Brotowidjoyo, M.D, Dj. Tribawono, E. Mulbyantoro. 1995. Pengantar Lingkungan Perairandan Budidaya Air

Barus, T. A. 1996. Metode Ekologis Untuk Menilai Kualitas Suatu Perairan Lotik

Effendi, H. 2003. Telaah Kualitas Air Bagi Pengelolaan Sumberdaya dan Lingkungan Perairan. 
Giyanto, Anna EW Manuputty, Muhammad Abrar, Riko M Siringoring 2014. Monitoring Terumbu Karang.

Hargreaves, J.A. dan Tucker, C.S. 2004. Managing Amonia in Fish Ponds. Southerm Regional Aquaculture Center

Keputusan Menteri Lingkungan Hidup No 51 tahun 2004 tentang Baku Mutu Air Laut.

Nontji, Anugerah., 2005. Laut Nusantara.

Cetakan Keempat. Djambatan. Jakarta.

Supriharyono, 2007. Konservasi Ekosistem Sumberdaya Hayati Di Wilayah Pesisir Dan Laut Tropis.

Supriharyono. 2000. Pelestarian dan Pengelolaan Sumber Daya Alam di Wilayah

Pesisir Tropis. Supriharyono, 2007. Konservasi Ekosistem Sumberdaya Hayati Di Wilayah Pesisir Dan Laut Tropis. 